\title{
Cultural Diversity and Development of Bangladesh
}

\author{
Dr. Kamrun Nahar \\ Assistant Professor, Department of Social Work, Sheikh Borhanuddin Post Graduate College.62, \\ Nazimuddin Road, Dhaka
}

\begin{abstract}
Cultural diversity is a common trend of Bangladesh which has been developed through the state of civilization and it influenced by different religions. This study is to find out the problems to conserve cultural diversity as well as analyze the existing laws to protect cultural archaeologies. Some legal barriers and administrative steps to protect cultural diversity and socio-economic development of Bangladesh. To review the existing laws, policies, and documents relevant with cultural identifications and diversifications is the prime method of this study. Bangladesh has rich cultural heritage for example pahela baishak, 21 February, religious festivals and national festivals which is effect on our socio-economic development indicators. Public, private and institutional interventions should be taken and implemented by the government authority for ensuring to protect the cultural diversity into the country.
\end{abstract}

Keywords: Cultural Diversity, Development Interventions, Bangladesh, Cultural Heritage

DOI: $10.7176 / \mathrm{JCSD} / 65-01$

Publication date:July $31^{\text {st }} 2021$

\section{Introduction}

Bangladesh has been the cradle of civilization, a center of cultural diffusion, since the dawn of history of mankind. It was the meeting ground of various peoples in different states of civilization, the most primitive as well as the most advanced. Influenced by the great religions - Islam, Hinduism, Buddhism and Christianity Bangladesh has been a melting pot of diverse races and confluence of civilizations. These major religions left footmarks of immense number of heritages that we take pride. Each phase of the history of Bangladesh has its distinct characteristics and every race of people who came and settled here, left its individual racial, religious or cultural impacts in the form of temples, stupas, monasteries and mosques along with their associated objects which all combine the heritages of Bangladesh. It is literally a multi-faced cultural collage. Its deep-rooted heritage is amply reflected in its architecture, literature, dance, drama, music and painting. Sculpture, tapestry, engravings are developing along the main stream contemporary art, drama, mainly of indigenous origin, has distinct feature. Pantomime, puppet, theatre, caricature, acrobatics and circuses have their own novelties. Music in Bangladesh has developed through centuries along the three mainstreams-folk, modern and classical. This paper will address some problems and prospects of cultural diversity in Bangladesh. Finally, some policy recommendations to the government how to ensure cultural diversity to cultural pluralism.

\section{Objectives}

- To find out problems to conserve the cultural diversity and archaeological heritage and how they influence on the economic development of Bangladesh.

- To analyse existing laws regarding cultural diversity.

- To find out legal barrier to preserve cultural diversity and development.

- To find out administrative steps to protect cultural diversity and socio-economic development of Bangladesh.

- To find out financial aspect of managing cultural diversity.

- To recommend some policy issues to the Government of the People's Republic of Bangladesh.

\section{Methodology}

- Cultural heritage related existing laws in Bangladesh like National Cultural Policies, 2006

- World report on cultural diversity 2009, UNESCO Constitution

- Convention of Biodiversity adopted in 1992 at Rio Earth Summit

- Experience gathered by visiting some archaeological sites and minorities area

\section{Scope of the Study}

Since Bangladesh is a rich country in terms of cultural diversity. In Bangladesh has many scopes for development through the cultural diversity. It has thousands year's history. Culture is the picture of the entire life of a sociality. So, there is huge scope to study on this subject. 


\section{Current Situation in Bangladesh}

The emergence of Bangladesh as an independent state was the result of a fight against violation of human rights in different ways. People's struggle for establishing fundamental rights by brushing aside anomalies is always there in this part of the world. But unfortunately, the polity is yet to overcome the barriers to human rights. Constitution is the supreme law of the country in which a lot of articles are there to ensure human rights as well as cultural diversity and also pluralism.

"Human Rights as guarantees of cultural diversity" According to article 4 of UNESCO Universal Declaration on Cultural Diversity, Bangladesh is abundant with constitutional provisions and statutory laws guaranteeing diverse freedom. Few of the articles are mentioned below:

- The state religion is Islam, but all other religions can be practiced in peace and harmony (Art.2A)

- The Republic shall be a democracy in which fundamental human rights and freedoms and respect for the dignity and worth of the human person shall be guaranteed (Art-11)

- Equality of opportunity (Art-17)

- Article 23 states that the State shall adopt measures to conserve the cultural tardyons and heritage of the people, and so to foster and improve of the national language, literature and the arts that all sections of the people are afforded the opportunity to contribute towards and to participate in the enrichment of the national culture.

- The State shall adopt measures for the protection against disfigurement, damage or removal of all monuments, objects or places of special artistic or historic importance or interest. (Article 24)

- No citizen shall, on grounds only of religion, race, caste, sex or place of birth be subjected to any disability, liability, restriction or condition with regard to access to any place of public entertainment or resort, or admission to any educational institution. (Article 28)

- Nothing in this article shall prevent the State from making special provision in favor of women or children or for the advancement of any backward section of citizens. (Article 28)

- No citizen shall, on grounds only of religion, race, caste, sex or place of birth be subjected to any disability, liability, restriction or condition with regard to access to any place of public entertainment or resort, or admission to any educational institution. (Article 28)

- Nothing in this article shall prevent the State from making special provision in favor of women or children or for the advancement of any backward section of citizens. (Article 28)

- Freedom of procession or occupation (Art-40)

- Every citizen has the right to profess, practice or propagate any religion;

- Every religious community or denomination has the right to establish, maintain and manage its religious institutions. (Article 41)

Bangladesh was among the first countries to sign and ratify the Convention of the Child in 1990. Bangladesh ratified the United Nations Convention on the Elimination of All Form of Discrimination against Women (the Convention), on 6 November 1984.

It is necessary to mention that recently High Court Division repealed the fifth amendment of the constitution in which secularism was cancelled. The present government of Bangladesh in line with High Court verdict wants to establish secular state banning Islamic parties.

\section{Cultural Diversity in Bangladesh}

People of Bangladesh irrespective their religion, caste etc. celebrate local and national cultural festival and also perform religious rituals freely. There are a number of organizations under the Ministry of Cultural Affairs in Bangladesh to diversity culture. Those are:

- Bangladesh Shilpakala Academy

- Bangla Academy

- Bangladesh National Museum

- Department of Archaeology

- Nazrul Institute

- $\quad$ Directorate of Archives \& Libraries

- Department of Public Libraries

- National Book Centre

- Copyright Office

- Bangladesh Folk Arts and Crafts Foundation

- Cox's Bazar Cultural Centre

- Tribal Cultural Institute, Bandarban 
- Tribal Cultural Institute, Rangamati

- Tribal Cultural Academy Birisiri, Netrokona

There are some other institutions to improve cultural pluralism and language which are as follows:

- Modern Language Institutions in Dhaka University

- Bangladesh National Philatelic Association

- Bangladesh Photographic Society

- Bishwa Sahitya Kendra (World Literature Centre)

- Mymensing Debate Federation

- National Heritage Foundation of Bangladesh

Some cultural programs of Bangladesh are mentioned below:

- Pahela Baishak is the first day of the Bangla Calendar. It is usually celebrated on the 14th of April every year. Usually on Pôhela Boishakh, the home is thoroughly scrubbed and cleaned; people bathe early in the morning and dress in fine clothes.

- Nabanno Utsab: on the occasion of new crops Bangladeshi celebrate cake festivals.

- Pahela Bashanto: Bangladesh has six seasons. At the first day of Spring Bangali boys and girls celebrate Bashanti wearing special dress. Girls wear yellow seri and boys wear colorful Panjabi.

- Ekushey (21) February: The national Mourning Day and the World mother Language movement Day is a unique part of the culture of Bangladesh. In 1999 UNESCO declared 21st February as International Mother Language Day commemorating the sacrifices for the language.

- Victory Day: After 9-month long war with Pakistani army at the cost of 3 million people Bangladesh got independence on 16th December1971. Since then, we celebrate the day as victory day.

- Eid-ul Fitr as the most important religious festival for the majority Muslims, the celebration of EidulFitr has become a part of the culture of Bangladesh

- Eid-ul Azha the celebration of Eidul-Adha is similar to Eidul-Fitar in many ways. The only big difference is the Qurbani or sacrifice of domestic animals on Eidul-Adha

- Durga Puja; is an annual Bengali festival that celebrates worship of Hindu goddess Durga. It refers to all the six days observed as Mahalaya, Shashthi, MahaSaptami, MahaAshtami, MahaNabami and Bijoya Dashami. The dates of Durga Puja celebrations are set according to traditional Bengali Calendar and the fortnight corresponding the festival is called Debi Pokkho

- Basanti Puja, the religious festival of the Hindu community, is being celebrated with much enthusiasm at Sree Sree Durga Mandir at the city's Zafrabad area in Rayer Bazar

- Christmas Day the Christian village men would cut down scores of banana trees and replant them in pairs along the paths to churches and outside their homes. They would then bend over the huge leaves of the banana trees to form an arch; they would then make small holes in the bamboo poles, fill them with oil and tie them across the arches. When the oil is lit, the way to the church is lit up bright enough for all to see.

- Buddha Purnima; Buddhist monasteries in Dhaka and across the country have been decorated with flags marking the festival. Recitation from the Buddhist sacred book Tripitak, breaking of fast by the monks and offering of "kathinchibordan" (presentation of yellow robes to the monks) were the special features of the celebrations. Special prayers are offered in all monasteries across the country seeking peace, progress and prosperity of the nation.

\section{Cultural Diversity Economic and Development}

Culture is the expression of human values. There is an urgent need to rethink the role of culture as we face up to the growing economic, environmental and social challenges of the new millennium because:

- Cultural resources are replacing natural resources as the primary raw material of economic growth.

- Cultural routes are often the most effective way of achieving non-cultural objectives, from health promotion or education to employment and economic growth;

- Cultural values shape our beliefs, acting as gatekeepers to development initiatives.

When it is used in different ways -in relation to art, design, heritage, community practices and more its specific use will be clear from the context. Our values, our beliefs, our culture have the greatest influence on our actions.

Culture makes money. Competitiveness in manufacturing and services depends less on productivity savings - doing more with less - and more on adding value to what we do. Cultural heritage, including monuments, landscapes and human practices, is also a major source of employment. Conservation works tend to require appropriate local skills and so provide quality work and training. With sensitive exploitation, cultural heritage of all kinds can be a crucial means of tourism development. Major tourism industries and cultural 
projects help spread visitors and their economic impact more widely, ensuring that a greater proportion of their spending stays in the country. Culture can be a source of rich and sustainable development or a brake on change, an obstacle and a source of division. local cultural resources - natural and man-made heritage, traditions, crafts, skills, ways of working, social organisation etc.-might contribute to achieving development objectives. The relationship between culture and the economy is changing, as is the way audiences experience and enjoy creative products such as film, music and other artistic expressions. In addition to providing opportunities for economic growth and employment, culture and cultural industries and cultural heritage are key vehicles within and amongst nations. Culture affects cities in two ways: in terms of the environment for doing business and because culture is a key resource for urban businesses.

Travel and tourism are one of the biggest and fastest-growing sectors of the global economy and is particularly significant in the developing world. Cultural tourism can play a role in sustaining and renewing indigenous cultural practices. Cultural tourism as an instrument of urban redevelopment. In Bangladesh has also great opportunity in this sector.

There are many cultural heritages in Bangladesh. World biggest unbroken sea beach is situated in Bangladesh. Culture is a major factor influencing how governance and human rights are conceptualized and put into practice.

- $\quad$ The specific political cultures of a country help determine how it is governed.

- The presence of specific cultural groups shapes a polity's approach to instituting rights.

- Governments communicate with citizens through the use of media, arts and music.

\section{Common cultural heritages of Bangladesh, Diversity among mainstream Bengali people and recommendations for preserving and improving those}

Although Bangladeshi nationals are relatively homogenous people compared to those of many other countries in the world, there are still distinct cultural diversities among these people as regards their heritage, lifestyle, language, occupation, art and crafts. There are people of main four religions namely Islam, Hinduism, Christianity and Buddhism in the country. Although all of them are Bengali by definition their religious identities are very important and that make them distinct among the broader "Bengali" genre. Therefore, they have some distinct cultural practices of their own based on their religions. There is sometimes intolerance among the people having faith in the majority religion about those practices. Government not only should enforce strict legal measures regarding these, but also promote awareness and education regarding the necessity of understanding and tolerant behavior. Article 1 of UNESCO Declaration of Principles of International Cultural Co-operation emphasizes that "Each culture has a dignity and value which must be respected and preserved." The government's line of action should also take this thing in consideration.

"All cultures form part of the common heritage of mankind. The cultural identity of a people is renewed and enriched through contact with the traditions and values of others. Culture is dialogue, the exchange of ideas and experience and the appreciation of other values and traditions; it withers and dies in isolation" is observed by Mexico City Declaration on Cultural policies. This is at the root of overall development of the nation.

Due emphasis should be placed upon achieving this goal. As for individual lives, increased sharing among people of different cultures is vital for the survival of cultural diversity in the country. A child should be taught in the home the values of culture and its practice.

Love and respect for cultural practices must be taught and explained to the young people at home because all the great values start at home. Teaching and practicing of cultural heritages and diversity are to be made in the educational institutions ranging from elementary to higher institutions.

Government and civil society have a responsibility to encourage diverse cultural practices through various programs and occasions organized throughout the country round the year. The balanced development of the people belonging to all cultural groups is the key to development and prosperity of the country.

\section{Policy Recommendations}

i. Government should make the archaeological department more active to conserve the archaeological heritage which is near to decay for this Ministry of Cultural Affairs has to give sufficient employee and more fund allocation to the department.

ii. Government should include UNESCO Universal Declaration on Cultural Diversity and action plan as text in educational institutions to educate the importance on that. For this Ministry of Education can gives responsibility to National Curriculum and Textbook Board (NCTB) which is it's subordinate office.

iii. Unprotected historical places should be brought under protection immediately making boundary wall. Taking a country wide project Ministry of Cultural Affairs can give a direction to local administration to make boundary wall and other protective measures for this financial allotment to be given by Ministry of Finance.

iv. All the existing laws including national cultural policy 2006 should be implemented, some laws to be 
amended. Law ministry will have to do the job. Because cultural policies are the true driving force in cultural diversity.

v. Some primary schools can be set up in indigenous people living area to teach indigenous language. Leader of the indigenous people through district administration has to send the proposal to the Ministry of Education.

vi. Indigenous people should be given incentive to participate in national cultural program. Bangladesh Shilpakala Academy will take initiative through local Tribal Cultural Institutes and academy.

vii. To foster minority's cultural diversity and pluralism some specific institutions like club, community centric can be set up by government initiative under the Ministry of Cultural Affairs.

viii. Judiciary should play more active role to ensure human rights. Office of Attorney General under Ministry of Law will take proper steps.

ix. Public Private Partnership to be enhanced to diverse cultural diversity to cultural pluralism. Ministry of Cultural Affairs will make partnership through its subordinate organizations.

x. State run media should be given autonomy so that they can equally highlight minorities and indigenous people's news and culture. Information Ministry has to play role for this.

xi. More cultural centers can be set up for minority and indigenous people. The Minister for indigenous people can set up the cultural centre from his development allocation by the central government. Millions of moneys are allocated to every MP and Minister to develop the respective area/ constitutions.

xii. To promote multiculturalism state should play neutral role, not support to a specific model of culture. Government and its employee should follow this principle.

xiii. More budgetary allocation should be given to cultural ministry to enhance cultural diversity as well as cultural pluralism. Ministry of Finance will have to give the allocation, in some cases they can consult with Planning Ministry.

xiv. Arrange intercultural dialogue which creates space for mutual perception and appreciation. District Shilpakala (arts institute) will arrange intercultural dialogue and cultural programs very often.

$\mathrm{xv}$. Importance to be given on the empowerment of marginalized communities which is prerequisite for multiculturalism. Parliament, central government and local government should implement this.

xvi. Anti-discriminatory policies should be incorporated into education and government programs so that the recognition of equal dignity is reinforced in every day's life. Ministry of Law, Justice and Parliamentary Affairs with collaboration of Education Ministry have to incorporate the policies.

xvii. Under Copy right Act 2000 (amended in 2005) registration of copy right is voluntary but it should make obligatory and more drive /punitive measures are needed to combat against piracy and artists rights by copy right office.

xviii.The idea that cultural policy is mainly the responsibility of national decision-makers and public administration is being replaced by a concept of 'creativity governance and management'.

xix. Increase awareness of the cultural approach to development among decision-makers, media professionals and development workers;

xx. Encourage planners, project directors and development workers to acquire the necessary knowledge and skills for a cultural approach to development.

xxi. In light of this, create a co-operation and research network among regional and national research and training institutions, professional associations, social science specialists and academics working on issues of culture and development.

xxii. Encourage the development among specialists of more open professional concepts and practices that are more receptive to the cultural approach to development;

xxiii.Elaborate, test and refine methodological tools, including specifically cultural indicators of development, with a view to gradually ensuring the widespread adoption of the cultural approach to development;

xxiv.Provide technical assistance to developing countries for the design of development strategies, policies, plans, programmes and projects based on the cultural approach;

xxv. Translate the results of fieldwork and data gathered from research into changes in medium-term strategies and programmes;

xxvi.Use the media and information services of organisations such as UNESCO and the African Itinerant College of Culture and Development in order to disseminate to the various target audiences the knowledge, experience and know-how acquired through training sessions and concomitant research work on the problems of culture and development.

The following issues have been among the principal priorities of national cultural policy makers across Europe during the past five years:

- The conservation, restoration and, in some countries, reconstruction of cultural heritage;

- Administrative reform including moves towards mixed systems of financing;

- Decentralisation of national government responsibilities for culture to regional or local levels 
and partnership arrangements with private sector actors;

- Modernisation or creation of arts and media legislation (especially in Eastern Europe);

- De-regulation of state intervention in the media including publishing, film and television;

- Arts or cultural education.

\section{Conclusion}

Culture, governance and human rights are inter-dependent. Literature, music, the arts as well as various forms of media are being used to promote good governance and human rights. Many forms of cultural expression are dependent on national or municipal structures not only for funding but also for supportive modes of governance. It ensures the rights of members of diverse cultural backgrounds to participate in a given polity. Thus, cultural citizenship entails both claiming political rights and building community. Cultural diversity is like bio-diversity. As bio-diversity is indispensable for the survival of nature and ecosystem, so is cultural diversity for the society, civilization and human kind. Ensuring human rights, minority rights, protecting cultural heritages and best practices, providing special considerations to those really deserving them and inter-cultural dialogue and understanding are keys to managing and nourishing cultural diversity in any country. If Government induce the existing organizations to ensure human rights as well as cultural diversity it would be easy to achieve new type of multicultural dimension. Government also can allocate specific responsibility to specific organization by which all the region will come under same border. Through the observance of Human Rights Day, we can grow more awareness among the disadvantages people about their rights. From the above discussion we can say that this is the time for cultural sustainability for which government, private, semi-public institutions, civil society, majority-minority everybody should come forward to protect common heritage, cultural diversity, human rights, cultural rights, environment, solidarity among the society and encourage linguistic diversity as per UNESCO universal declaration on cultural diversity and action plan for its implementation.

\section{References}

Copyright Law, 2000

Human Development Report, 2004, UNDP

Mexico City Declaration on Cultural Policies, 1982

Ministry of Cultural Affairs' website: http://www.moca.gov.bd/

Ministry of Education's website: http://www.moedu.gov.bd/

Ministry of Law, Justice and Parliamentary Affairs website: http:// www.minlaw.gov.bd

National Encyclopedia of Bangladesh

National Archives Ordinance, 1983

National Cultural Policy of Bangladesh, 2006

The Constitution of the People's Republic of Bangladesh

The Antiquities Law, 1968

UNESCO Universal Declaration on Cultural Diversity 2001

UNESCO Constitution

UNESCO Universal Declaration on Cultural Diversity

World report on cultural diversity 2009

World cultural report 2000

World Report on Cultural Diversity, 2009

Wikipedia: Culture of Bangladesh 